\title{
Amyloid beta mediates memory formation
}

\author{
Ana Garcia-Osta ${ }^{1,3}$ and Cristina M. Alberini ${ }^{1,2,4}$ \\ ${ }^{1}$ Department of Neuroscience, Mount Sinai School of Medicine, New York, New York 10029, USA; ${ }^{2}$ Department of \\ Psychiatry, Mount Sinai School of Medicine, New York, New York 10029, USA
}

\begin{abstract}
The amyloid precursor protein (APP) undergoes sequential cleavages to generate various polypeptides, including the amyloid $\beta$ (1-42) peptide (A $\beta[1-42])$, which is believed to play a major role in amyloid plaque formation in Alzheimer's disease (AD). Here we provide evidence that, in contrast with its pathological role when accumulated, endogenous $A \beta$ in normal hippocampi mediates learning and memory formation. Furthermore, hippocampal injection of picomolar concentrations of exogenous $A \beta(1-42)$ enhances memory consolidation. Correlative data suggest that $A \beta$ peptides may exert their function via nicotinic acethylcoline receptors. Hence, $A \beta$ peptides, including $A \beta(1-42)$, play an important physiological role in hippocampal memory formation.
\end{abstract}

The amyloid precursor protein (APP) is a multifunctional protein that is highly conserved throughout evolution and abundantly expressed in neurons and glia. Its proteolytic processing results in the production of different fragments depending on the secretase involved. The nonamyloidogenic processing of APP by $\alpha$-secretase leads to the release of secreted APP (sAPP)- $\alpha$ and prevents the formation of $A \beta$ peptides (Allinson et al. 2003). Conversely, in the amyloidogenic pathway, the cleavage of APP by $\beta$ - and $\gamma$-secretases generates amyloid beta peptides $(\mathrm{A} \beta)$, which consist largely of $39-43$ amino acids residues. Of these, the $A \beta(1-40)$ is the most common form, whereas $A \beta(1-42)$ is the most fibrillogenic and believed to be associated with disease states, such as early-onset Alzheimer's disease (AD) and memory disorders (Price and Sisodia 1998; Haass 2004). Indeed, a variety of studies have indicated that elevation and accumulation of $\mathrm{A} \beta$ levels result in cognitive dysfunction, including memory deficits (Haass and Selkoe 2007). Intracerebral administration of high concentrations (nanomolarmicromolar range) of $A \beta$ peptides, which mimics $A \beta$ accumulation in $\mathrm{AD}$, disrupts the retention of both spatial and contextualfear memories, as well as short-term working memory in rodents (Flood et al. 1991; Cleary et al. 1995; Maurice et al. 1996; Sipos et al. 2007). Notably, it appears that soluble $A \beta$ oligomers, rather than large $A \beta$ aggregates or deposits, are responsible for disrupting the mechanisms underlying learning and memory, particularly during the earliest stages of $\mathrm{AD}$. In fact, the accumulation in the brain of normal rats of $A \beta$ oligomers alters the cellular correlates of memory long-term potentiation and long-term depression and impairs memory retention (Cleary et al. 2005; Walsh and Selkoe 2007; Irvine et al. 2008; Shankar et al. 2008).

In contrast to the accumulation found in pathological states, in normal brains, $A \beta$ peptides are produced at lower concentrations, which has been estimated to be in the range of 200-1000 $\mathrm{pM}$, with $\mathrm{A} \beta(1-42)$ at the lower end of this range and $\mathrm{A} \beta(1-40)$ at the higher (Cirrito et al. 2003; Ramsden et al. 2003). Whether these concentrations of $A \beta$ peptides play physiological functions in normal conditions still remains to be determined. Previous studies have implicated APP or its metabolites in synapse formation, maintenance and growth, in neurite extension, and, intriguingly, in synaptic plasticity and learning and memory

${ }^{3}$ Present address: CIMA, University of Navarra, CIBERNED, Pamplona 31008, Spain.

${ }^{4}$ Corresponding author.

E-mail cristina.alberini@mssm.edu; fax (212) 996-9785

Article is online at http://www.learnmem.org/cgi/doi/10.1101//m.1310209.
(Senechal et al. 2006). APP knockout mice are impaired in longterm potentiation as well as spatial and avoidance learning and memory (Muller et al. 1994; Dawson et al. 1999; Seabrook et al. 1999). Drosophila lacking the fly homolog for APP (Appl) shows impaired avoidance learning that can be rescued by the expression of the human APP gene (Luo et al. 1992). Furthermore, antibodyor antisense-mediated blockade of APP during an early phase of memory formation disrupts inhibitory avoidance in chicks (Mileusnic et al. 2000). Conversely, intraventricular administration of the secreted form of APP results in memory enhancement and rescues the amnesia induced by the cholinergic antagonist scopolamine (Meziane et al. 1998). Finally, intracerebral or intraventricular administration of antibodies that bind to various domains of APP, including the middle portion of the A $\beta$ fragment, disrupts learning and memory in rats (Doyle et al. 1990; Huber et al. 1993), suggesting that the role of APP in memory formation could be mediated by $\mathrm{A} \beta$.

Here, we hypothesized that, in contrast to the functional impairments that result from their accumulation, in normal brains, $A \beta$ peptides, including $A \beta(1-42)$, play physiological functions, one of which is to mediate learning and memory formation. To test this hypothesis, we determined the effect on memory retention of either blocking endogenous $A \beta$ or enhancing $A \beta(1-$ 42) concentration in the hippocampus, a region known to be critically involved in the formation of explicit memories (Squire 1992).

For these experiments, we used inhibitory avoidance (IA), a fear conditioning-based task, in which the animal (rat) learns to associate a context with a mild foot shock and subsequently develops avoidance for that context. This memory is known to require an intact hippocampus and its consolidation process depends on hippocampal gene expression (Taubenfeld et al. 2001; Tronel et al. 2005; Garcia-Osta et al. 2006; Canal and Gold 2007). The IA behavioral procedures, dorsal hippocampal cannula implants, and intrahippocampal injections employed in these experiments were the same as described in previous studies from our laboratory (Taubenfeld et al. 2001; Tronel et al. 2005; see Garcia-Osta et al. 2006) (both 0.6 and $0.9 \mathrm{~mA}$ shock intensity were used to assess $\mathrm{A} \beta[1-42]$ modulation while $0.9 \mathrm{~mA}$ shock intensity was used to assess memory disruption after antibody or antagonist experiments).

In the first set of experiments, we tested whether the in vivo sequestration of endogenous $A \beta$ in the hippocampus affects IA memory. Toward this end, we used the monoclonal antibody antiA 4 G8 (Millipore) (Marksteiner and Humpel 2008). This antibody is specific for the $A \beta$ ectodomain (amino acid sequence 17-24 in human) (Kim et al. 1990; Johnson et al. 2002), a sequence that 
does not overlap with that of sAPP and is identical in human, rat, and mouse. Adult Long-Evans rats (200-250 g) were implanted with cannulae that bilaterally targeted the hippocampi as previously described (Taubenfeld et al. 2001; Garcia-Osta et al. 2006). One week after recovery from surgery, the animals were divided into two groups. Fifteen minutes before training, one group received bilateral hippocampal injections of $1 \mu \mathrm{g}$ of anti-A $\beta$ antibody in a volume of $1 \mu \mathrm{L}$, and the other received the same concentration and volume of a control monoclonal antibody of the same subclass (control mAb, antiIg2A, Santa Cruz). Each group was divided in two subgroups. One subgroup from each treatment ( $n=6$ for each treatment) was tested for short-term memory (STM) at $1 \mathrm{~h}$ after training. The other two subgroups ( $n=9$ each) were tested for long-term memory (LTM) retention $24 \mathrm{~h}$ after training. As shown in Figure 1A, the anti-A $\beta$ completely disrupted STM retention $(28.2 \pm 7.1 \mathrm{sec})$ compared to the control antibody $(379.9 \pm$ $62.4 \mathrm{sec}, P<0.001$; student $t$-test). LTM was also significantly disrupted by the anti-A $\beta(150.1 \pm 36.4 \mathrm{sec})$ compared to the control mAb antibody (408.5 $\pm 62.4 \mathrm{sec}$; Fig. 1B). The disruption persisted $5 \mathrm{~d}$ after training and memory did not recover following a reminder foot shock of the same intensity administered in a different context one day later $(P<0.01$ and $P<0.001$, two- way ANOVA followed by Bonferroni post-hoc test). To confirm that the hippocampi were not damaged by the treatment, the rats that received anti-A $\beta$ were finally retrained $24 \mathrm{~h}$ after the final test. As shown in Figure 1B, retraining resulted in normal memory retention $24 \mathrm{~h}$ later.

To further dissect whether the role of $A \beta$ is important during the training phase or the post-training phase of memory consolidation-the process by which memory becomes strengthened over time (Lechner et al. 1999) - we repeated the experiment but injected the antibodies immediately after training. Thus, groups of rats were bilaterally implanted with cannulae targeting the dorsal hippocampus and, one week after surgery, were trained in IA. Immediately after training, half of the rats received injections of $1 \mu \mathrm{g}$ of either anti-A $\beta(n=7)$ or the control mAb $(n=6)$. Memory retention was tested $24 \mathrm{~h}$ after training. As shown in Figure $1 \mathrm{C}$, no effect was found and both groups of rats had similar memory retention (anti-A $\beta$ : $381.0 \pm 69.1 \mathrm{sec}$; control mAb: 417.4 $\pm 72.8 \mathrm{sec}$ ). To determine whether an effect of treatment emerged at later times, we retested both groups $5 \mathrm{~d}$ after training. No effect was found at this time point either (Fig. 1C).

In order to exclude that the pre-training injection of anti-A $\beta$ caused nonspecific effects, we tested both locomotor activity $(n=$ $5 /$ group) and nociceptive sensitivity (hot plate test, $n=5$ (group) of rats injected with anti-Aß or control $\mathrm{mAb}$. As shown in Figure 1D,E, neither test revealed an effect of treatment.

Together, these results suggest that hippocampal $A \beta$ plays a critical role in memory formation and exerts its function during the learning phase and/or a narrow time window immediately thereafter.

We then asked: Is the amnesia resulting from the administration of the anti-A $\beta$ due to the selective depletion of endogenous $A \beta$, and can this amnesia be rescued by exogenous $A \beta(1-42)$ administered at a physiological concentration range? To address this question, we tested whether the administration of picomolar concentrations of exogenous human $\mathrm{A} \beta(1-42)$ rescues the amnesia produced by the anti-A $\beta$ antibody (Fig. 2). Fifteen minutes before training, rats received a bilateral injection of a combination of $0.451 \mathrm{pg}(100 \mathrm{pM})$ of oligo/monomeric preparations of human $\mathrm{A} \beta(1-42)$ or relative scrambled control peptide with $1 \mu \mathrm{g}$ of either anti-A $\beta$ or control antibody in a total volume of $1.5 \mu \mathrm{L}$ per side. Preparations consisting of oligomers and monomers (oligo/monomers; Fig. 2A) of human $A \beta(1-42)$ (American Peptide) and scrambled $A \beta(1-42)$ (Anaspec) were obtained as described by Dahlgren et al. (2002). The oligo/momomers preparations and antibodies were mixed before the injection and kept on ice until the solution was injected. Memory was tested $24 \mathrm{~h}$ after training. As depicted in Figure $2 \mathrm{~B}$, rats that received the control $\mathrm{mAb}$ together with $A \beta(1-42)$ showed a significantly enhanced memory retention (500.5 $\pm 40.2 \mathrm{sec} ; n=6)$ compared to those that received $\mathrm{mAb}$ and scrambled 
A

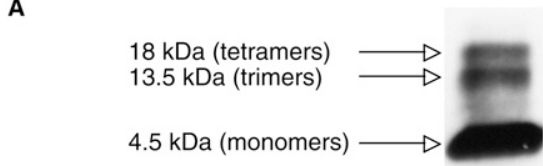

B

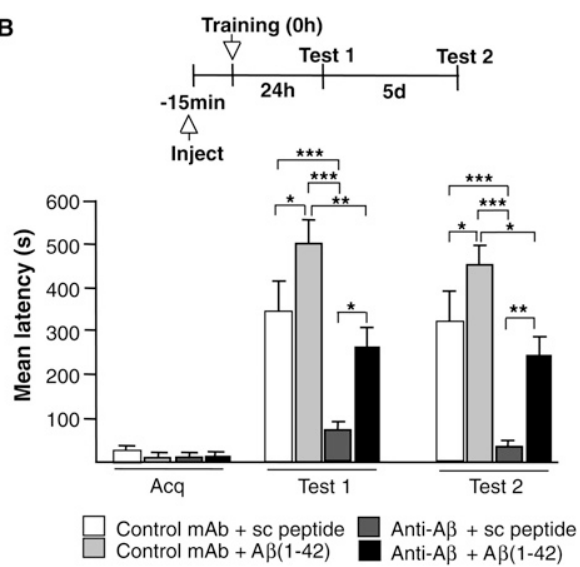

C

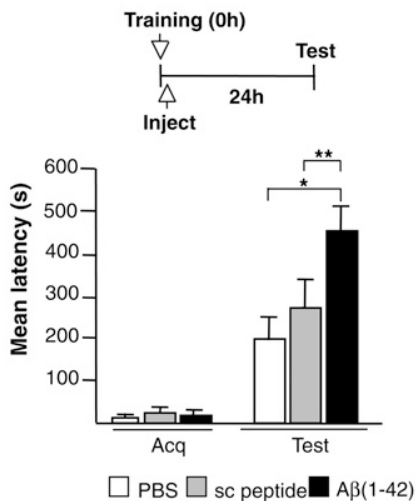

Figure 2. Memory impairment produced by the depletion of endogenous $A \beta(1-42)$ is rescued by exogenous oligomeric human $A \beta(1-42)$. (A) Oligo/monomeric preparation of $A \beta 42$ was examined by $4 \%-12 \%$ tris-tricine nondenaturing PAGE Western blotting (Garcia-Osta et al. 2006) using the anti-A $\beta$ monoclonal antibody $6 \mathrm{E} 10$ (Covance Research 1:1000) (Tomiyama et al. 2008). Bands corresponding to tetramers, trimers, and monomers were detected. (B) Memory acquisition (Acq) and retention are expressed as mean latency \pm SEM (in seconds, s). Rats received intrahippocampal injections of either anti-A $\beta$ or control mAb antibody combined with either scrambled (sc) peptide or $\mathrm{A} \beta(1-42) 15$ min before IA training. ${ }^{*} P<0.05,{ }^{* *} P<0.01,{ }^{* * *} P<0.001$. Test $1,24 \mathrm{~h}$ after training; Test 2, $5 \mathrm{~d}$ after training. (C) Memory acquisition (Acq) and retention expressed as mean latency \pm SEM (s) of rats that received intrahippocampal injections of PBS, sc peptide, or $A \beta(1-42)$ immediately after IA training. Administration of $A \beta(1-42)$ immediately after IA training enhances memory retention $24 \mathrm{~h}$ after training. ${ }^{*} P<0.05,{ }^{* *} P<0.01$.

peptide $(343.2 \pm 65.5 \mathrm{sec} ; n=8 ; P<0.05$, one-way ANOVA followed by Newman-Keuls post-hoc test). Confirming our previous results shown in Figure $1 \mathrm{~B}$, the rats that received injections of anti-A $\beta$ together with scrambled peptide had a significant memory impairment $(71.1 \pm 10.0 \mathrm{sec} ; n=8, P<0.001$, two-way ANOVA followed by Newman-Keuls post-hoc test). Conversely, when exogenous human $A \beta(1-42)$ was administered together with the anti-A $\beta$ antibody, memory retention was rescued (263.1 \pm $64.6 \mathrm{sec} ; n=6$ ). Indeed, a significant difference was found between this group and the group that received the scrambled peptide and the anti-A $\beta$ antibody $(P<0.05$, two-way ANOVA followed by
Newman-Keuls post-hoc test). Subsequent retention tests $5 \mathrm{~d}$ after training revealed that the effects of treatments were persistent (Fig. $2 \mathrm{~B})$. Hence, physiological concentration of $\mathrm{A} \beta$ peptides, including $A \beta(1-42)$, mediates learning and memory formation.

Given that $A \beta(1-42)$ in picomolar concentration promoted memory enhancement when injected before training, we investigated whether it also modulates the consolidation of IA memory. One week after recovery from hippocampal surgery, rats trained on IA received a bilateral injection of $100 \mathrm{pM}$ per side, in $1 \mu \mathrm{L}$, of either oligo/monomeric preparation of human $\mathrm{A} \beta(1-42)(n=12)$ or scrambled peptide $(n=8)$ immediately after training. Additional controls were injected with the same volume of vehicle solution (PBS, $n=4)$ to determine whether injections of peptides, in general, nonspecifically affect memory retention. As depicted in Figure $2 C$, rats that received $A \beta(1-42)$ showed a significant enhancement in memory retention $(459.2 \pm 44.3 \mathrm{sec})$ compared to both vehicle-injected $(199.4 \pm 46.7 \mathrm{sec}, P<0.05)$ and scrambled peptide-injected rats $(242.5 \pm 57.8 \mathrm{sec}, P<0.01) 24 \mathrm{~h}$ after training (one-way ANOVA followed by Newman-Keuls post-hoc test), indicating that the administration of physiological concentrations of $A \beta(1-42)$ enhances memory retention.

Together, these results indicate that endogenous $A \beta$ plays a critical role during learning for both short- and long-term memory formation and that $\mathrm{A} \beta(1-42)$ in low concentrations (picomolar range) modulates memory consolidation.

It has been reported that $A \beta(1-42)$ binds selectively and with picomolar affinity to $\alpha 7$ nicotinic acetylcholine receptors (nAchR) (Wang et al. 2000a, b). If this is true, then, similar to the depletion of endogenous $A \beta(1-42)$, pre-training inhibition of hippocampal nAchRs should disrupt memory retention, while the post-training inhibition should have no effect. Indeed, we found this to be the case. Rats were bilaterally injected into the hippocampus, either 15 min before or immediately after IA training, with $25 \mu \mathrm{g}$ in $1 \mu \mathrm{L}$ per side of the cholinergic receptor antagonist mecamylamine (MCA) (Sigma; Ohno et al. 1993; Vago and Kesner 2007). STM retention was tested $1 \mathrm{~h}$ after training and LTM was tested $24 \mathrm{~h}$ after training. Only the pre-training bilateral injections produced a significant memory impairment at both short- (veh: $298.8 \pm 59.9 \mathrm{sec}$; MCA: $86.1 \pm 26.3 \mathrm{sec}, n=8$ per group, $P<0.01)$ and long-term time points (veh: $385.0 \pm 61.8 \mathrm{sec}$; MCA: $25.2 \pm 4.6 \mathrm{sec}, n=8$ per group, $P<0.001$; Fig. 3A), whereas post-training administration had no effect on either short- (veh: $217.5 \pm 59.2$ sec; MCA: 280.6 $\pm 67.4 \mathrm{sec}, n=8$ per group) or long-term retentions (veh: $345.8 \pm$ $84.7 \mathrm{sec}$; MCA: $312.2 \pm 67.7 \mathrm{sec}, n=8$ per group; Fig. $3 \mathrm{~B})$. Neither locomotor activity nor nociceptive sensitivity was affected by MCA treatment (Fig. 3C,D; $n=5$ per group), excluding that the memory impairments obtained with this treatment were due to nonspecific effects.

Hence, similar behavioral outcomes are evoked by hippocampal treatments that block the function of either endogenous $A \beta$ or nAchRs, suggesting, in agreement with previous literature (Chin et al. 2007), that $A \beta(1-42)$ might exert its modulatory function on memory formation via interaction with nAchRs.

Together, our results show that, first, bilateral injections into the hippocampus of an anti-A $\beta$ antibody before but not after training dramatically disrupt memory formation. Second, intrahippocampal administration of picomolar concentrations of exogenous $A \beta(1-42)$ following training enhances memory retention. Thus, we propose that $A \beta$ peptides, including $A \beta(1-42)$, produced or present at the time of training, play a critical role in mediating memory formation.

Our data are in agreement with and extend previous observations indicating that, in many species from invertebrates to mammals, and with different types of learning, APP is critically involved in memory formation (Senechal et al. 2006). As most of these previous studies were based on APP gene knockout or 
A

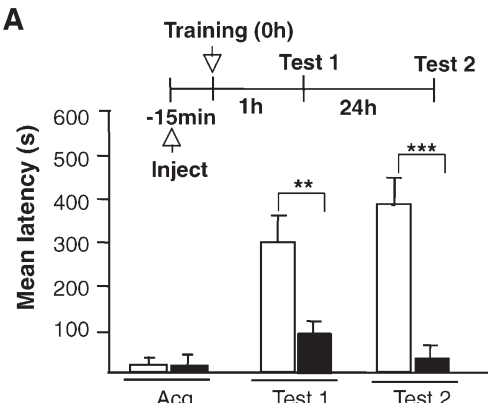

C

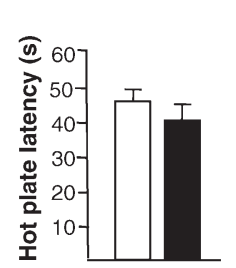

B

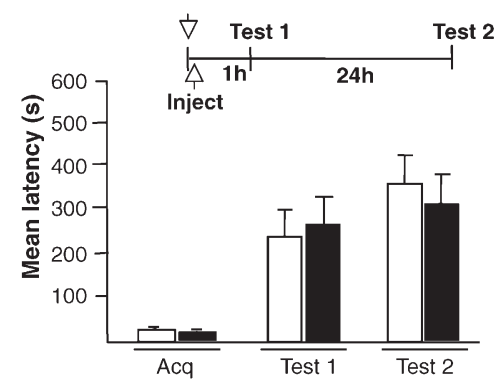

D

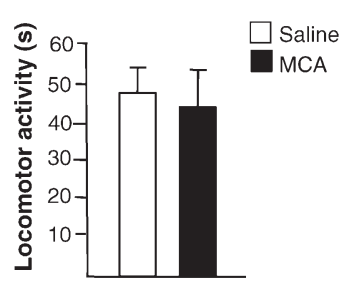

Figure 3. The nicotinic receptor antagonist mecamylamine (MCA) mimics the effect of the anti$A \beta(1-42)$ antibody. Memory acquisition (Acq) and retention expressed as mean latency \pm SEM (in seconds, s) of rats that received intrahippocampal injections of saline or MCA 15 min before IA training $(A)$ or immediately after IA training (B). STM was tested $1 \mathrm{~h}$ after training and LTM was tested $24 \mathrm{~h}$ after training. ${ }^{* *} P<0.01,{ }^{* * *} P<0.001$. (C) Effect of intrahippocampal injection of saline or MCA on nociceptive hot plate test. Rats injected with MCA or saline underwent the hot plate test 15 min after injection (Carter 1991). Values are the mean \pm SEM of response latencies measured in seconds. No difference in hot plate latencies was detected between the two groups. $(D)$ Effect of intrahippocampal injection of saline or MCA on locomotor activity. One hour after injection of either saline or MCA rats were tested for locomotor activity as described in Figure 1 . Values are the mean \pm SEM of motility counts. No difference in locomotor activity was detected between the two groups.

knockdown approaches, they could not distinguish whether it was APP or its metabolites, and particularly $A \beta$ peptides, that play a critical role in learning and memory formation (Doyle et al.1990; Huber et al. 1993). In agreement with our findings, several studies had indicated that $A \beta$ processing as well as the activation of the $A \beta$ processing enzymes, such as the $\beta$ site APP cleaving enzyme 1 (BACE1), $\gamma$ - and $\varepsilon$-secretases (Nitsch et al. 1992; Kamenetz et al. 2003), are regulated by neuronal activity and facilitate learning and memory and synaptic plasticity (Ma et al. 2007). Furthermore, genetic ablation of BACE1 or presenilin-1, the catalytic component of the $\gamma$ - and $\varepsilon$-secretase complexes, profoundly reduces or eliminates $A \beta$ and APP intracellular domain (AICD) production and causes amnesia in mice (Dawson et al. 1999; Yu et al. 2001; Ohno et al. 2004; Laird et al. 2005). Our data extend these findings and support the conclusion that $A \beta$ is critically recruited at the time of training or immediately thereafter to promote memory formation and that the amyloidogenic $A \beta(1-42)$ can modulate memory consolidation. Our data do not exclude that other $A \beta$ peptides, e.g., $A \beta(1-40)$, whose sequence overlaps with that of $A \beta(1-42)$, or peptides that bear the same epitope might have similar modulatory functions on learning and memory, and additional studies should be able to further address this issue. We speculate that $A \beta(1-42)$, recruited during learning, critically mediates an early phase of synaptic changes that, via signal transduction, leads to protein and RNA synthesis-dependent long-term memory consolidation. Further experiments testing the effect of $A \beta$ on other memory tasks will also help in determining whether this is a general mechanism underlying memory formation.

An important question that remains to be addressed is why $A \beta$, and in particular $A \beta(1-42)$, which is mainly known to cause memory impairment, can, like in the present study, mediate of these investigations, whicholine receptors. Unfortunately, most of these investigations, which produced controversial results, have assessed the role of nanomolar concentration of $A \beta(1-42)$. Some studies have reported that $A \beta(1-42)$ activates nAChRs (Dineley et al. 2002; Dougherty et al. 2003; Fu and Jhamandas 2003), whereas others indicated that $A \beta(1-42)$ inhibits nAChRs (Pettit et al. 2001; Wu et al. 2004; Lamb et al. 2005). Interestingly, Dougherty et al. (2003) reported that, while nanomolar concentrations of $A \beta(1-42)$ inhibited nicotine-induced $\mathrm{Ca}^{2+}$ responses, picomolar $A \beta(1-42)$ directly evoke sustained increases in presynaptic $\mathrm{Ca}^{2+}$ via nAChRs, implying that the apparent inhibitory action of $A \beta(1-42)$ is the result of an occlusion of nicotine to further stimulate the receptors. The direct effect of $A \beta(1-42)$ was found to be sensitive to $\alpha$-bungarotoxin, mecamylamine, and dihydro- $\beta$-erythroidine, indicating involvement of nAChRs. Because the activation of nAChRs can modulate presynaptic, glutamate-mediated synaptic transmission or glutamate release, it is in line with our hypothesis that $A \beta(1-42)$, in picomolar concentrations, may contribute to a nicotinic modulatory response recruited during LTM consolidation. Indeed, nAChRs can influence excitatory events in the hippocampus (Ge and Dani 2005), and one of the key targets of endogenous cholinergic modulation involved in cognition is the NMDAR-mediated transmission (Chen et al. 2008). Thus, the binding of $A \beta$ to nAChRs might regulate NMDA-mediated excitatory neurotransmission in physiological conditions during learning.

In conclusion, we propose that a physiological role of $A \beta$ peptides, including $A \beta(1-42)$, is to mediate memory formation via nicotinic acetylcholine receptor interaction.

Our data suggest that $A \beta(1-42)$ should not be regarded only as a toxic factor that has to be eliminated to avoid dementia and $\mathrm{AD}$. Our results add to the evidence suggesting important physiological roles for $A \beta$ peptides. 


\section{Acknowledgments}

This work was supported by grants R01 MH065635 to C.M.A. We thank the members of the laboratory and in particular Dillon Chen and Gabriella Pollonini for technical support and reading of the manuscripts, and Reginald Miller and the Center for Comparative Medicine and Surgery facility at Mount Sinai School of Medicine for technical support.

\section{References}

Allinson, T.M., Parkin, E.T., Turner, A.J., and Hooper, N.M. 2003. ADAMs family members as amyloid precursor protein $\alpha$-secretases. J. Neurosci. Res. 74: 342-352.

Canal, C.E. and Gold, P.E. 2007. Different temporal profiles of amnesia after intra-hippocampus and intra-amygdala infusions of anisomycin. Behav. Neurosci. 121: 732-741.

Carter, R.B. 1991. Differentiating analgesic and non-analgesic drug activities on rat hot plate: Effect of behavioral endpoint. Pain 47: 211220.

Chen, G., Chen, P., Tan, H., Ma, D., Dou, F., Feng, J., and Yan, Z. 2008. Regulation of the NMDA receptor-mediated synaptic response by acetylcholinesterase inhibitors and its impairment in an animal model of Alzheimer's disease. Neurobiol. Aging 29: 1795-1804.

Chin, J.H., Ma, L., MacTavish, D., and Jhamandas, J.H. 2007. Amyloid $\beta$ protein modulates glutamate-mediated neurotransmission in the rat basal forebrain: Involvement of presynaptic neuronal nicotinic acetylcholine and metabotropic glutamate receptors. J. Neurosci. 27: 9262-9269.

Cirrito, J.R., May, P.C., O'Dell, M.A., Taylor, J.W., Parsadanian, M., Cramer, J.W., Audia, J.E., Nissen, J.S., Bales, K.R., Paul, S.M., et al. 2003. In vivo assessment of brain interstitial fluid with microdialysis reveals plaqueassociated changes in amyloid- $\beta$ metabolism and half-life. J. Neurosci. 23: $8844-8853$.

Cleary, J., Hittner, J.M., Semotuk, M., Mantyh, P., and O'Hare, E. 1995. Betaamyloid (1-40) effects on behavior and memory. Brain Res. 682: 69-74

Cleary, J.P., Walsh, D.M., Hofmeister, J.J., Shankar, G.M., Kuskowski, M.A., Selkoe, D.J., and Ashe, K.H. 2005. Natural oligomers of the amyloid- $\beta$ protein specifically disrupt cognitive function. Nat. Neurosci. 8: 79-84.

Dahlgren, K.N., Manelli, A.M., Stine, Jr., W.B., Baker, L.K., Krafft, G.A., and $\mathrm{LaDu}$, M.J. 2002. Oligomeric and fibrillar species of amyloid- $\beta$ peptides differentially affect neuronal viability. J. Biol. Chem. 277: 32046-32053.

Dawson, G.R., Seabrook, G.R., Zheng, H., Smith, D.W., Graham, S., O'Dowd, G., Bowery, B.J., Boyce, S., Trumbauer, M.E., Chen, H.Y., et al. 1999. Age-related cognitive deficits, impaired long-term potentiation and reduction in synaptic marker density in mice lacking the $\beta$-amyloid precursor protein. Neuroscience 90: 1-13.

Dineley, K.T., Bell, K.A., Bui, D., and Sweatt, J.D. 2002. $\beta$-Amyloid peptide activates $\alpha 7$ nicotinic acetylcholine receptors expressed in Xenopus oocytes. J. Biol. Chem. 277: 25056-25061.

Dougherty, J.J., Wu, J., and Nichols, R.A. 2003. $\beta$-Amyloid regulation of presynaptic nicotinic receptors in rat hippocampus and neocortex. $J$. Neurosci. 23: 6740-6747.

Doyle, E., Bruce, M.T., Breen, K.C., Smith, D.C., Anderton, B., and Regan, C.M. 1990. Intraventricular infusions of antibodies to amyloid- $\beta-$ protein precursor impair the acquisition of a passive avoidance response in the rat. Neurosci. Lett. 115: 97-102.

Flood, J.F., Morley, J.E., and Roberts, E. 1991. Amnestic effects in mice of four synthetic peptides homologous to amyloid- $\beta$ protein from patients with Alzheimer disease. Proc. Natl. Acad. Sci. 88: 3363-3366.

$\mathrm{Fu}, \mathrm{W}$. and Jhamandas, J.H. 2003. $\beta$-Amyloid peptide activates non- $\alpha 7$ nicotinic acetylcholine receptors in rat basal forebrain neurons. $J$. Neurophysiol. 90: 3130-3136.

Garcia-Osta, A., Tsokas, P., Pollonini, G., Landau, E., Blitzer, R., and Alberini, C.M. 2006. MuSK expressed in the brain mediates cholinergic responses, synaptic plasticity and memory formation. J. Neurosci. 26: 7919-7932.

Ge, S. and Dani, J.A. 2005. Nicotinic acetylcholine receptors at glutamate synapses facilitate long-term depression or potentiation. J. Neurosci. 25: 6084-6091.

Haass, C. 2004. Take five-BACE and the $\gamma$-secretase quartet conduct Alzheimer's amyloid $\beta$-peptide generation. EMBO J. 23: 483-488.

Haass, C. and Selkoe, D.J. 2007. Soluble protein oligomers in neurodegeneration: Lessons from the Alzheimer's amyloid $\beta$-peptide. Nat. Rev. Mol. Cell Biol. 8: 101-112.

Huber, G., Martin, J.R., Löffler, J., and Moreau, J.L. 1993. Involvement of amyloid precursor protein in memory formation in the rat: An indirect antibody approach. Brain Res. 603: 348-352.

Irvine, G.B., El-Agnaf, O.M., Shankar, G.M., and Walsh, D.M. 2008. Protein aggregation in the brain: The molecular basis for Alzheimer's and Parkinson's diseases. Mol. Med. 14: 451-464.
Johnson, L.V., Leitner, W.P., Rivest, A.J., Staples, M.K., Radeke, M.J., and Anderson, D.H. 2002. The Alzheimer's A $\beta$-peptide is deposited at sites of complement activation in pathologic deposits associated with aging and age-related macular degeneration. Proc. Natl. Acad. Sci. 99: 1183011835.

Kamenetz, F., Tomita, T., Hsieh, H., Seabrook, G., Borchelt, D., Iwatsubo, T., Sisodia, S., and Malinow, R. 2003. APP processing and synaptic function. Neuron 37: 925-937.

Kim, K.S., Wen, G.Y., Bancher, C., Chen, C.-M.J., Sapienza, V.J., Hong, H., and Wisniewski, H.M. 1990. Detection and quantitation of amyloid $\beta$-peptide with 2 monoclonal antibodies. Neurosci. Res. Commun. 7: $113-122$.

Laird, F.M., Cai, H., Savonenko, A.V., Farah, M.H., He, K., Melnikova, T., Wen, H., Chiang, H.C., Xu, G., Koliatsos, V.E., et al. 2005. BACE1, a major determinant of selective vulnerability of the brain to amyloid- $\beta$ amyloidogenesis, is essential for cognitive, emotional, and synaptic functions. I. Neurosci. 25: 11693-11709.

Lamb, P.W., Melton, M.A., and Yakel, J.L. 2005. Inhibition of neuronal nicotinic acetylcholine receptor channels expressed in Xenopus oocytes by $\beta$-amyloid $1-42$ peptide. J. Mol. Neurosci. 27: 13-21.

Lechner, H.A., Squire, L.R., and Byrne, J.H. 1999. 100 years of consolidation—remembering Müller and Pilzecker. Learn. Mem. 6: 7787.

Luo, L., Tully, T., and White, K. 1992. Human amyloid precursor protein ameliorates behavioral deficit of flies deleted for Appl gene. Neuron 9: 595-605.

Ma, H., Lesne, S., Kotilinek, L., Steidl-Nichols, J.V., Sherman, M., Younkin, L., Younkin, S., Forster, C., Sergeant, N., Delacourte, A., et al. 2007. Involvement of $\beta$-site APP cleaving enzyme 1 (BACE1) in amyloid precursor protein-mediated enhancement of memory and activitydependent synaptic plasticity. Proc. Natl. Acad. Sci. 104: 81678172.

Marksteiner, J. and Humpel, C. 2008. $\beta$-Amyloid expression, release and extracellular deposition in aged rat brain slices. Mol. Psychiatry 13: 939952.

Maurice, T., Lockhart, B.P., and Privat, A. 1996. Amnesia induced in mice by centrally administered $\beta$-amyloid peptides involves cholinergic dysfunction. Brain Res. 706: 181-193.

Meziane, H., Dodart, J.C., Mathis, C., Little, S., Clemens, J., Paul, S.M., and Ungerer, A. 1998. Memory-enhancing effects of secreted forms of the $\beta$-amyloid precursor protein in normal and amnestic mice. Proc. Natl. Acad. Sci. 95: 12683-12688.

Mileusnic, R., Lancashire, C.L., Johnston, A.N., and Rose, S.P. 2000. APP is required during an early phase of memory formation. Eur. J. Neurosci. 12: 4487-4495.

Muller, U., Cristina, N., Li, Z.W., Wolfer, D.P., Lipp, H.P., Rulicke, T., Brandner, S., Aguzzi, A., and Weissmann, C. 1994. Behavioral and anatomical deficits in mice homozygous for a modified $\beta$-amyloid precursor protein gene. Cell 79: 755-765.

Nitsch, R.M., Slack, B.E., Wurtman, R.J., and Growdon, J.H. 1992. Release of Alzheimer amyloid precursor derivatives stimulated by activation of muscarinic acetylcholine receptors. Science 258: 304-307.

Ohno, M., Yamamoto, T., and Watanabe, S. 1993. Blockade of hippocampal nicotinic receptors impairs working memory but not reference memory in rats. Pharmacol. Biochem. Behav. 45: 89-93.

Ohno, M., Sametsky, E.A., Younkin, L.H., Oakley, H., Younkin, S.G., Citron, M., Vassar, R., and Disterhoft, J.F. 2004. BACE1 deficiency rescues memory deficits and cholinergic dysfunction in a mouse model of Alzheimer's disease. Neuron 41: 27-33.

Pettit, D.L., Shao, Z., and Yakel, J.L. 2001. $\beta$-Amyloid ${ }_{1-42}$ peptide directly modulates nicotinic receptors in the rat hippocampal slice. J. Neurosci. 21: $1-5$.

Price, D.L. and Sisodia, S.S. 1998. Mutant genes in familial Alzheimer's disease and transgenic models. Annu. Rev. Neurosci. 21: 479-505.

Ramsden, M., Nyborg, A.C., Murphy, M.P., Chang, L., Stanczyk, F.Z., Golde, T.E., and Pike, C.J. 2003. Androgens modulate $\beta$-amyloid levels in male rat brain. I. Neurochem. 87: 1052-1055.

Roesler, R., Vianna, M.R., de-Paris, F., Rodrigues, C., Sant'Anna, M.K. Quevedo, J., and Ferreira, M.B. 2000. NMDA receptor antagonism in the basolateral amygdala blocks enhancement of inhibitory avoidance learning in previously trained rats. Behav. Brain Res. 112: 99-105.

Seabrook, G.R., Smith, D.W., Bowery, B.J., Easter, A., Reynolds, T., Fitzjohn, S.M., Morton, R.A., Zheng, H., Dawson, G.R., Sirinathsinghji, D.J., et al. 1999. Mechanisms contributing to the deficits in hippocampal synaptic plasticity in mice lacking amyloid precursor protein. Neuropharmacology 38: 349-359.

Senechal, Y., Larmet, Y., and Dev, K.K. 2006. Unraveling in vivo functions of amyloid precursor protein: Insights from knockout and knockdown studies. Neurodegener. Dis. 3: 134-147.

Shankar, G.M., Bloodgood, B.L., Townsend, M., Walsh, D.M., Selkoe, D.J., and Sabatini, B.L. 2007. Natural oligomers of the Alzheimer amyloid- $\beta$ protein induce reversible synapse loss by modulating an NMDA-type 
glutamate receptor-dependent signaling pathway. J. Neurosci. 27: 2866-2875.

Shankar, G.M., Li, S., Mehta, T.H., Garcia-Munoz, A., Shepardson, N.E., Smith, I., Brett, F.M., Farrell, M.A., Rowan, M.J., Lemere, C.A., et al. 2008. Amyloid- $\beta$ protein dimers isolated directly from Alzheimer's brains impair synaptic plasticity and memory. Nat. Med. 14: 837842.

Sipos, E., Kurunczi, A., Kasza, A., Horvath, J., Felszeghy, K., Laroche, S., Toldi, J., Parducz, A., Penke, B., and Penke, Z. 2007. $\beta$-Amyloid pathology in the entorhinal cortex of rats induces memory deficits: Implications for Alzheimer's disease. Neuroscience 147: 28-36.

Squire, L.R. 1992. Memory and the hippocampus: A synthesis from findings with rats, monkeys, and humans. Psychol. Rev. 99: 195-231.

Taubenfeld, S.M., Milekic, M., Monti, B., and Alberini, C.M. 2001. The consolidation of new but not reactivated memory requires hippocampal C/EBPß. Nat. Neurosci. 4: 813-818.

Tomiyama, T., Nagata, T., Shimada, H., Teraoka, R., Fukushima, A. Kanemitsu, H., Takuma, H., Kuwano, R., Imagawa, M., Ataka, S., et al. 2008. A new amyloid $\beta$ variant favoring oligomerization in Alzheimer'stype dementia. Ann. Neurol. 63: 377-387.

Tronel, S., Milekic, M., and Alberini, C.M. 2005. Linking new information to a reactivate memory requires consolidation but not reconsolidation mechanisms. PLoS Biol. 3: e293. doi: 10.1371/journal.pbio.0030293.
Vago, D.R. and Kesner, R.P. 2007. Cholinergic modulation of Pavlovian fear conditioning in rats: Differential effects of intrahippocampal infusion of mecamylamine and methyllycaconitine. Neurobiol. Learn. Mem. 87: 441-449.

Walsh, D.M. and Selkoe, D.J. 2007. Aß oligomers-a decade of discovery. J. Neurochem. 101: 1172-1184.

Wang, H.Y., Lee, D.H., D'Andrea, M.R., Peterson, P.A., Shank, R.P., and Reitz, A.B. 2000a. $\beta$-Amyloid ${ }_{1-42}$ binds to $\alpha 7$ nicotinic acetylcholine receptor with high affinity. Implications for Alzheimer's disease pathology. I. Biol. Chem. 275: 5626-5632.

Wang, H.Y., Lee, D.H., Davis, C.B., and Shank, R.P. 2000b. Amyloid peptide $\mathrm{A} \beta(1-42)$ binds selectively and with picomolar affinity to $\alpha 7$ nicotinic acetylcholine receptors. J. Neurochem. 75: 1155-1161.

Wu, J., Kuo, Y.P., George, A.A., Xu, L., Hu, J., and Lukas, R.J. 2004 $\beta$-Amyloid directly inhibits human $\alpha 4 \beta 2$-nicotinic acetylcholine receptors heterologously expressed in human SH-EP1 cells. J. Biol. Chem. 279: 37842-37851.

Yu, H., Saura, C.A., Choi, S.Y., Sun, L.D., Yang, X., Handler, M., Kawarabayashi, T., Younkin, L., Fedeles, B., Wilson, M.A., et al. 2001. APP processing and synaptic plasticity in presenilin-1 conditional knockout mice. Neuron 31: 713-726.

Received December 15, 2008; accepted in revised form February 17, 2009. 


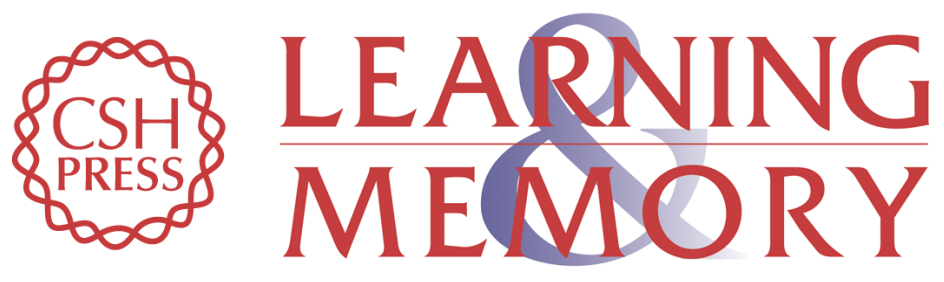

\section{Amyloid beta mediates memory formation}

Ana Garcia-Osta and Cristina M. Alberini

Learn. Mem. 2009, 16:

Access the most recent version at doi:10.1101//m.1310209

References This article cites 56 articles, 19 of which can be accessed free at: http://learnmem.cshlp.org/content/16/4/267.full.html\#ref-list-1

License

Email Alerting Receive free email alerts when new articles cite this article - sign up in the box at the Service top right corner of the article or click here. 